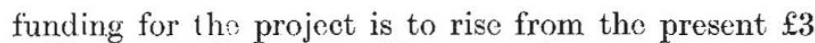
million annually to $£ 5$ million over the next five years.

Following Black Arrow on the launching pads at Woomera was the F8 test flight of ELDO'S Europa 1 rocket, still grounded earlier this week due to weather conditions. After the failure of the German third stage during the F7 test last November, F8 contains a number of modifications including the replacement of several rigid pipes in the third stage by flexible tubing. F8 will again be an orbital attempt with a light test satellite ballasted to weigh about $1,000 \mathrm{lb}$ so as to test the rocket with a payload having a high centre of gravity. But only about $411 \mathrm{lb}$ of the payload is intended to separate from the third stage and go into orbit. The next firing, F9, is expeeted in November and will be the last Fl. DO launch planned for Woomera. After that the ELDO launch complex in French Guiana is to be used.

Although the end of Britain's commitment to ELDO is in sight, British cooperation with NASA is flourishing. Two satellites in the Ariel series are in the pipelineUK4 and UK5-and both are to be built in Britain. UK4 is planned for launch in mid-1971 and is to contain five experiments concerned with interactions between chargcd particles and electromagnetic waves in the upper atmosphere-four British and one American. Out of seven applicants for the space allotted to the United States, an experiment put forward by Dr L. A. Frank of the University of Iowa has been selected (Dr Frank is a member of Professor J. A. Van Allen's group). UK5 is still at the planning stage, and three British firms are in the running for the role of prime contractor. The decision whether or not to go ahead with the satellite, which is to be of the observatory type possibly with American participation in the experiments, is expected later this year.

\section{LIBERAL SCIENCE}

\section{Appreciuted by Industry}

THE case with which the first students to graduate from the "Science Greats" course at the University of Manchester have found jobs is encouraging for the champions of more broadly based science courses in Britain. It may even encourage a few other universities to take the plunge and start liberal science courses aimed at showing how the natural sciences interact with economics, government policies and human values. Lamentably, Manchester's course is at present unique in Britain. The few other universities that have made noises in this dircction have still not progressed much beyond the faculty meeting stage.

According to Mr B. J. Holloway, secretary of the university's appointments board, the thirtecn liberal science graduates were "some of the most marketable students at Manchester this year". All but one, who has not yet decided what to apply for, have jobs in industry, the universities or science journalism. Blue chip companies, such as IBM, ICT, Kodak and International Computers, have obviously been impressed by the graduates. One has an SRC Science and Industry Award to enable him to return from ICI to a university for postgraduate work and four are going directly to universities for postgraduate work with a noticcable vocational bias.
Professor F. R. Jevons, who takes the lion's share of the credit for the course and its success, is more than satisfied with the way his pupils have found jobs. His only regrets are that none entered the open competition for the administrative grade of the civil service and none is going into school teaching. As he says, one or two might have done so but for the attractive offers they received from industry. That, and the fect that four out of the thirteen students got firsts, five upper seconds and only one a third, is the sort of news that proves the remarkable efficiency of the student bush telegraph. Science Greats at Manchester can obviously look forward to an increasing number of applicants for the eighteen or, at a squeeze, twenty places it can offer each year.

\section{ISOTOPES}

\section{Market-building for Californium}

The US Atomic Encrgy Commission secms bent on creating a market for californium-252, an artificial isotope of element 98 . The commission has distributed a brochure describing the potential benefits of the isotope to a variety of possible uscrs, and has offered to lend sources containing californium-252 to those wishing to make detailed studies with them. The brochure contains the promise that the AEC would be prepared to manufacture substantial quantities of the isotope in its reactors at the Savannah River Plant if a sizable demand should eventually matcrialize.

The sales talk for californium-252 stems almost entirely from the way in which the isotope can be used as an intense neutron source. For this reason, the AEC brochure suggests that the material could be uscd in medicine for neutron radiotherapy and for radiography. Yet another possibility is that neutrons from californium-252 could be used for the production of shortlived radioactive isotopes - chlorine-38 and manganese-56 are two of those singled out by the AFC for special mention. Evidently the isotope could also be a convenient tool for neutron activation analysis, and the brochure points out that the material might be particularly useful in the remote analysis of the surface material on the planets.

Apart from being a conveniently intense source of neutrons, californium-252 scems to have the advantage that it can be obtained from americium-243 and curium-244. These isotopes are likely to be produced in large quantities from the power programme now building up in the United States. One estimate is that the production of these fecd materials for the production of californium-252 will amount to tens of kilograms a year in the 1970 s and ten times as much a decade later. It is therefore prudent of the $\mathrm{AEC}$ to attempt to find a market for what will otherwise be perishable waste products. It seems already to be clear that nuclear reactors will also, by the eighties, be more prolific sources of rare metals such as rhodium and palladium than the crust of the Earth itself. Thus it has been estimated that United States power reactors will be producing 74,000 troy ounces of rhodium a year in 1984, compared with a current demand for 55,000 troy ounces a year. Reactor wastes will evidently provide rich pickings for the utility companies in the decades ahead. 